\title{
Floods fail to save canyon beaches
}

\author{
IMAGE \\ UNAVAILABLE \\ FOR COPYRIGHT \\ REASONS
}

\section{PHOENIX, ARIZONA}

River habitats along the Grand Canyon, which have been eroding because of a dam upstream, may never return to their natural state, admit Earth scientists. In a report released last week, they conclude that floodwater experimentally released into the river did not carry enough sediment to rebuild the area's eroded beaches.

The report reviews more than ten years of work, and was released at the Colorado River Ecosystem Science Symposium, held in Tempe, Arizona, from 25 to 27 October. In the study, the researchers say that a flood released in 2004 created some sandbars in the upper reaches of the river, but admit the effect was short-lived.

The Colorado River, which runs along the Grand Canyon in Arizona, used to be brown with sediment. It was flanked by extensive beaches and sandbars that provided habitat for species found nowhere else. The humpback chub (Gila cypha) is one such species - a fish with degenerate eyes and a prominent hump that stabilizes it in the river's swirling waters.

However, in 1963 the Glen Canyon Dam, which is now the major power source in the southwestern United States, was completed. As a result, the river downstream of the dam runs slow and clear, the beaches and sandbars have eroded dramatically, and the humpback chub is critically endangered.

In 1996, after years of debate, scientists at the US Geological Survey agreed on a plan to restore the ecosystem. They hoped that releasing a massive flood through the dam would shift sediment trapped at the bottom of the river and rebuild the beaches. Later that year, they pumped an extra 1,290 cubic metres of water per second down the canyon for a week, at an estimated cost to power companies of $\$ 2.5$ million. It was a failure - there just was not enough sediment in the river to redistribute (see Nature 420, 356-358; 2002).

In 2004 they tried again, timing the flood to coincide with an annual release of sediment from the Paria River, just downstream of the Glen Canyon Dam. But despite high hopes, this failed too. The results "directly contradict" rosy predictions made in 1996, says the scientists' report, which concludes that the only way to rebuild the sandbars permanently is with a continuous source of new sediment.
The Colorado River has been deprived of silt by a dam - with fatalconsequences for local fauna.

"Full restoration of the river is impossible," says John Schmidt, a geomorphologist at Utah State University in Logan, who helped to plan the 1996 and 2004 floods. "It is a much more difficult challenge than anticipated." He says it's time for Americans to realize that they cannot have a huge power-generating dam and a natural river ecosystem.

But others continue to look for solutions. The US Bureau of Reclamation, which operates the dam, is thinking about piping sediments into the Colorado River from a lake that has been created upstream of the installation, Lake Powell. A sediment transport system would be a momentous engineering endeavour, estimated to cost at least $\$ 100$ million to build and a further $\$ 10$ million a year to operate. Even if the project is funded, it may take a decade to complete.

In the meantime, efforts to save the humpback chub, including culling the invading trout that feed on it, are not working. Scientists at last week's symposium presented results showing that more than half of the 10,000 chub that thrived a decade ago are now gone.

Rex Dalton 